\title{
PART-TIME WORK AS A FLEXIBLE WORK ARRANGEMENT (EUROPEAN CONTEXT)
}

\author{
Nataliya P. Mokrytska ${ }^{1^{*}}$, Mariya S. Dolynska ${ }^{2}$ \\ ${ }^{1,2}$ Department of Economic and Legal Disciplines, Faculty of Law, Lviv State University of Internal Affairs, Lviv, \\ Ukraine. \\ Email: " phd.university@yahoo.com
}

Article History: Received on $17^{\text {th }}$ August 2019, Revised on $30^{\text {th }}$ September 2019, Published on $07^{\text {th }}$ November 2019

\begin{abstract}
Purpose of the study: The main criterion for choosing a model of the organization of the workflow by the employer is the cost-effectiveness and rationality of using labor resources. It is proved that the greatest efficiency of the working process can be achieved through the correct combination of full-time work with elements of part-time employment. It seems possible to enshrine such models of labor relations at the level of the legislation of the EU and individual countries by introducing appropriate amendments to labor legislation.
\end{abstract}

Methodology: Hermeneutics, formal-logical and comparative law were used as the main methodological tools. In addition, the methods of systemic and structural analysis were used to identify the most successful mechanisms for the legal regulation of relations in the field of part-time employment. The study of the provisions of local regulations governing contractual relations was of particular success in achieving the research results.

Main Findings: A conclusion was made that the transition to part-time employment can only take place within the labor relations between the employee and the employer. It is achieved through a combination of the means of contractual practices such as early notification of the other party (initiative) and negotiations aimed at resolving all issues related to changing working conditions. It has been found that most of the legislative rules are aimed at workers of medium-sized and large enterprises, certain categories of employees and duration of relations.

Applications of this study: The study has an extended practical application. First of all, it can be used for developing the most effective modern mechanisms of part-time employment at the level of national legislation. The conclusions and the results of the study can also be used by companies in developing intra-corporate regulations.

Novelty/Originality of this study: All types of effective HR management models based on part-time employment have been identified for the first time based on the transition from full-time to part-time work or vice versa. It was also proved for the first time with the help of scientific methodology, that the transition to part-time employment can only take place within the framework of labor relations between the employee and the employer.

Keywords: Employment Contract, part-time work, operational requirements of the establishment, transfer from full-time to part-time work or vice versa, international standards for part-time work, work arrangement.

\section{INTRODUCTION}

Significant changes in the labor market, its reorientation that aimed at adjustment in employment relationships create new challenges and unresolved issues for science and practice. All this led to the situation when the borders between stability and flexibility of the work process, the borders between the right and the duty are erased. It all happened under the influence of the efficiency criterion when the economic interests became more important than relationships between employers and workers.

Part-time work is the most noticeable among all the forms of employment, which can be connected to the implementation of the right to work. A special feature of part-time work is the ability to modify the duration of the working time of the employee. It promotes not only employment but also helps to hold a position when you need to combine work and private life.

Moreover, the European Court of Human Rights (2019) resolved that implementation of the right to part-time work is a component of the right to personal autonomy and development guaranteed by Article 8 of the Convention on Human Rights in order to reconcile private life with work, household duties and bringing up children.

During the second half of 2017, the level of part-time employed citizens was constantly increasing. But despite this or thanks to this, the highest employment rate in the European Union (235.4 million people) (European Commission, 2017b) was recorded during the second half of 2017. At the same time, part-time employment is most often applied by employers to labor relations with women: $31.4 \%$ of the total number of employed women works part-time. In labor relations with male workers, the proportion of those who work part-time is $8.2 \%$. This indicates that employers are flexible enough in using part-time work as a form of employment (Eurostat, 2017). The scope of employment mainly covers education and agriculture, including "other non-market services, such as health and social work, as well as market services, accommodation and food services, etc." (International Labour Office, 2018)

Eurostat data confirm that approximately 19 percent of employees are part-timers. In 2016, the highest rate of part-time work was recorded in the Netherlands (46.6\%), followed by Austria, Germany, Belgium, the United Kingdom, Sweden, 
Denmark, and Ireland. At the same time, part-time work as a form of employment is less commonly used by employers in Bulgaria (1.9\% of employed) as well as Hungary, Croatia, the Czech Republic, and Slovakia (4.8\%to 5.7 \%) (Eurostat, 2017).

In 2017-2018, there were suggestions for amending two international documents that are intended to improve the working conditions of part-time workers. They are Directive 2003/88/EC concerning certain aspects of the organization of working time (The European Parliament and the Council, 2003) and Directive of the European Parliament and of the Council on work-life balance for parents and caretakers (European Commission, 2017a). Suggested documents may become an effective tool in the fight against undeclared work. There are frequent cases when employers use labor force full time while signing a part-time contract with employees. Thus, there is an illegal minimization of tax deductions and violation of workers' labor rights (European Commission, 2016).

In addition, the Interinstitutional Proclamation on the European Pillar of Social Rights (2017) states that information about employment conditions and protection in case of dismissals and work-life balance (with the right to flexible working arrangements) is a component of fair working conditions. At the same time, "in accordance with legislation and collective agreements, the necessary flexibility for employers to adapt swiftly to changes in the economic context shall be ensured" (Interinstitutional Proclamation on the European Pillar of Social Rights, 2017).

Moreover, the topicality of the chosen research is explained by the introduction of new technologies in building organizational structures and organization of the working procedure. The concept of part-time employment is not a disadvantage of the state's economy or a negative phenomenon for the employer. The application of such a flexible mechanism as part-time employment is a simultaneous combination of the network system of labour organization, minimization of the employer's administrative and organizational costs, and also a new vision of the outsourcing mechanism.

At the same time, the main goal of this study is to analyze the current tendencies and standards of state regulation of parttime employment, including through the example of the EU law and the experience of European corporations. It must be understood that part-time employment is not a restriction of labor rights of citizens, but a new instrument for rationalizing the economic activity of the population and the economic activity of business entities.

\section{LITERATURE REVIEW}

Part-time employment is internationally considered as a special flexible form of employment associated with voluntary part-time work representing the participation of women and work-life balance.

A study by the Commission's Directorate-General for Employment, Social Affairs, and Inclusion provided that part-time work is a female phenomenon (European Commission, 2018, p.104).

Eurostat determines that most often people choose part-time work for family or personal reasons (from 2006), which include school education or training, illness or disability, looking after children or incapacitated adults (European Commission/Eurostat, 2019).

Blazquez Cuesta and Moral-Carcedo (2014), studying the labor market in terms of part-time work in Denmark, France, Italy, the Netherlands, and Spain, distinguished one of the most important features of this kind of employment. It is about the flexibility that, according to the authors, can help workers balance work and family life, and increase women's labor force participation (Blázquez Cuesta \&Moral Carcedo, 2014). Similar opinions shared by Shagvaliyeva and Yazdanifard (2014), admitting that flexible working hours promote and facilitate work-life balance.

Galea, Houkes and De Rijk (2014) concluded that when flexible working hours are supported by management and fit the work culture, they are highly appreciated both for private and work-related reasons.

Combined with flexible working hours, part-time work is used in practice as an effective means of overcoming unemployment (Kyyrä, Arranz\&García-Serrano, 2017). In their study, authors conclude that "increased employee flexibility over scheduling would help address underemployment in terms of both hours and skill grade" (Silim\& Stirling, 2014).

It should also be noted that part-time employment, as a form of employment, can sometimes be used as a means of counteracting unemployment. In order not to dismiss workers, employers have the opportunity to transfer them to part-time employment, even despite having full employment contracts signed with them. This reduces the costs of employers and, at the same time, allows workers to hold their partial income.

According to authors, "in cases where the employee is restricted or "forced" to accept a contract with limited working hours when he/she seeks a contract for longer hours or full-time employment, he/she is confined to involuntary part-time work" (Kjeldstad\&Nymoen, 2012).

An important role in the development of better flexible working policies is played by EUROFOUND and the ILO. In particular, EUROFOUND (2016) is studying EU regulation on work duration. 
The study conducted by the International Labour Office (ILO) (2016) compares part-time work with other legal forms of non-standard employment around the world, distinguishing between "traditional" and marginal part-time work.

The research results demonstrate that employers are constantly in search of more optimal models of work time management. At the same time, an important aspect, in this case, is obligatory minimization of labor costs. That is why part-time employment is a very efficient mechanism that allows using of employees' working time with optimal costs for employer. Part-time work is especially relevant for employers who need to use labor to implement projects that require partial but constant involvement of some specialists for a long time. Flexibility, mobility of workers, combination of working time of different specialists for solving a specific task are the main advantages of part-time work. In addition, it should be remembered that part-time work is an excellent example of illustrating the social responsibility of employers. This allows saving on employees, implementing social guarantees and reduce unemployment. Part-time work is the most effective mechanism for organizing the work of employees in times of crisis when there is an urgent need to reduce employer costs.- avoid long sentences - convert into simple sentences.

Devicienti, Grinza, and Vannoni (2015) also examine the impact of part-time employment on employer productivity. In particular, they divide part-time employment into horizontal and vertical. They explore separate influences of horizontal, vertical, and mixed part-time work, finding that the horizontal component has the greatest negative impact on part-time work, while they found no significant impact for the vertical model, Cataldi, Kampelmann and Rycx (2013) use matched employer-employee panel data on Belgian private-sector firms to estimate the relationship between part-time work/wage/productivity differentials.

Nelen, De Grip and Fouarge (2011) outlined the results of their study on the impact of part-time employment on firm productivity in the service sector.

The report of Beatson (2019) also indicates the uneven distribution of flexible employment across the economy - between public and private sectors, large and small employers, men and women.

\section{RESEARCH METHODOLOGY}

As part of this study, a consistent analysis of scientific literature, articles, and research by leading experts in the field of labor law was conducted. The main emphasis was placed on the analysis of part-time work as a form of labor organization. Using part-time employment allows employers to optimize the costs and maximize the efficiency of using the labour potential of workers. Current EU legislation was also analyzed in the field of regulation of part-time employment relations. For example, the following documents were analyzed: Council Directive 91/533/EEC (1991) on an employer's obligation to inform employees of the conditions applicable to the contract or employment relationship; Council Directive 97/81/EC (1998) concerning the Framework Agreement on part-time work concluded by UNICE, CEEP and the ETUC; European Commission' documents and even court practice. Both analyzes: the results of scientific research and legal adjusting of part-time work - were carried out independently. Their results formed the basis for conclusions regarding the advantages and disadvantages of using part-time employment. At the next stage of the research, an analysis of the current state of the use of employment in the EU countries was conducted using Eurostat data. The final stage of the study is a systematic analysis of the mechanism, which allows employers to combine full and part-time employment.

\section{RESEARCH FINDINGS}

A number of significant disadvantages of Council Directive 91/533/EEC (1991) have been identified. First of all, there is a lack of clarity in determining the legal consequences for employers seeking part-time workers. Therefore, it was proposed to use a synthesis of the legal adjusting of part-time employment by combining the mechanisms enshrined in EU law and the national law of EU member states. It was noted that partial employment should be regulated no less rigidly than fulltime employment. Therefore, it was concluded that it is necessary to enshrine specific terms and duration of the working day at the level of internal local schedules at the enterprise. This makes it possible to introduce a project management system for working time at the level of synthesis of mechanisms for full and part-time employment. We also considered a transition from full-time to part-time or vice versa as an important element of enterprise cost management.

\section{DISCUSSION}

\section{International standards of the legitimacy of part-time work agreement}

Implementation of the international legal standard of the right to part-time work began with the adoption of the International Labour Organization Convention 175 on Part-Time Work (ILO, 1994) and Part-Time Work Recommendation, 1994 (ILO, 1994a), and ended with the adoption of the European Framework Agreement on Part-Time Work (Council Directive 97/81/EC, 1998), which aimed at "contributing to the European strategy on employment and combating discrimination against part-time workers” (Sciarra, 2004).

However, none of these documents defines the law-enforcement concept of part-time work; they only outline the general approach to the wording of this definition in national legislation, with the possibility to determine the minimum duration of working hours of the employment contract. 
We agree that "international standards do not limit the reasons for entering into agreements on part-time work, the term of their validity, the minimum duration of part-time work, and do not establish the special maximum duration allowed for part-time work" (Petrylaite, 2014).

One of the most important principles is the principle of pro rata temporis, (Cuesta \&Martın, 2009) the application of which is connected with the vast range of case law of the European Court of Justice concerning part-time work.

European Working Time Directive can serve as a supplement to the international legal regulation for the EU countries, which content allows us concluding that working hours for part-time workers are the time when a worker performs his/her labor function "at the employer's disposal" (The European Parliament and the Council, 2003).

According to the Article 9 of Part-Time Work Convention, "productive and freely chosen part-time work" must correspond to both the interests of the employee and the employer, with "special attention, in employment policies, to the needs and preferences of specific groups such as the unemployed, workers with family responsibilities, older workers, workers with disabilities and workers undergoing education or training" (ILO, 1994).

If you correlate this provision with Article 12.1 of The ILO Part-Time Work Recommendation, the essence of part-time work consists of "the number and scheduling of hours of work of part-time workers" (ILO, 1994).

Part-time employment is a separate special type of labor organization in the enterprise. It allows minimizing economic costs and optimizing labor potential. Part-time work can also increase labor productivity and optimize the working and free time of employers. From the point of view of legal regulation, part-time employment is a special type of labor relations, but the specifics of such regulation are, first and foremost, the creation of guarantees for the adequate payment for workers. The importance of legal regulation of part-time employment is the need for its legitimization and prevention of abuse by employers in this context.

If the employment relationships occurred without written arrangements, the employer would inform the employee in writing of the working conditions not later than 2 months from the date of the beginning of work in accordance with the provisions of Article 3-4 of Council Directive 91/533/EEC (1991).

However, among the major components of such information about the working conditions, there is only the length of the employee's normal working day or week (Council Directive 91/533/EEC, 1991), without specifying the individual schedule of work.

The procedure of written notification of working conditions laid down in Council Directive 91/533/EEC(1991). This procedure has a number of shortcomings, which has led to the need for changes to be made at the international level in order to establish more stringent notification rules. In particular, it is proposed to determine the work schedule to be the essential condition, which should include the days and hours with the indication of the dates of starting and finishing work. In addition, the terms of written notification are proposed to be significantly reduced, namely, no later than the first day of work, the electronic means of notifications shall not be excluded. In case of missing terms, it is proposed to give the employer another 15 days to eliminate this omission (European Commission, 2017).

Consequently, it can be concluded from the above provisions that if the employee and the employer do not agree on the issue of an individual work schedule during the conclusion of an employment contract, and the content itself, with an indication of the part-time employment or the number of working hours, it is possible to apply the presumption of full-time employment.

The situation is much more complicated when part-time work actually exists, but there is no formalized employment relationship between the employee and the employer. This is about the so-called hidden labor relations (Report V(1) The Employment Relationship, 2006).

The concept of the actual existence of employment relationships has been improving by judicial practice for a long time (European Union Court of Justice, 2014), but the provision, which was made by a court decision in 1986, remains uncontested, according to which "the essential feature of an employment relationship, however, is that for a certain period of time a person performs services for and under the direction of another person in return for which he receives remuneration" (European Union Court of Justice, 1986).

A person is deprived of independence and flexibility, since such features are available only in connection with the achievement of an agreement between the employee and the employer, and are not a measure of a person's separation from the integration into the industrial and economic process of the employer. That is, after the conclusion of the employment contract, even a part-time contract, a person's work is reflected on the results of economic activity, its objectives, tasks, goals, for the achievement of which the employer hires labor force. Although in this case the employee is not responsible for the entrepreneurial risks and his/her responsibility is limited by the provisions of labor law. Reduced duration of working time describes a dimension of time for not only achieving the aggregate result but for performing certain tasks in connection with the implementation of the labor function.

So, registering the schedule in any document signed by the parties can testify to the existence of employment relationships. 
Consequently, the condition of an individually agreed employee timetable includes a clear distribution of shorter working hours within the relevant working schedule. Therefore, it is extremely important to determine the time of starting and finishing work, this is, in fact, a work schedule with an indication by days of the week.

\section{Transfer from full-time to part-time work or vice versa}

Although the Part-Time Work Convention, 1994 (ILO, 1994) does not provide for, the ILO Part-Time Work Recommendation No. 182 (ILO, 1994a) provides for the need for early notification in the event of changes in agreed work schedule. Please note that these are cases where one of the parties wants to make changes to the mutually agreed schedule of work of employees, which again refers to paragraph 12.1 of the ILO Part-Time Work Recommendation No. 182 (ILO, 1994a).

In addition to that, Article 10 of the Part-Time Work Convention provides for the concept: "transfer from full-time to parttime work or vice versa is voluntary, in accordance with national law and practice" (ILO, 1994).

A more detailed explanation of this provision is provided in The ILO Part-Time Work Recommendation (ILO, 1994a), where the emergence of a new job allows the employee to initiate a transfer from full-time to part-time work or vice versa by submitting an application to the employer, which, if possible, employers should take into consideration.

The similar provision of The ILO Part-Time Work Recommendation (ILO, 1994a) is reflected in Directive 2003/88/EC (The European Parliament and the Council, 2003) concerning certain aspects of the organization of working time, with the difference that the employer is obliged to promptly inform their employees of such a vacancy. For example, in accordance with the labor legislation of Moldova, the employer must bring the availability of such vacant positions to the notice of the employees and their representatives within 5 working days from the date when they occur. The form of the notification is also determined at the legislative level. It is a public announcement that is placed on the information public stand at the location of the employer (including subsidiaries), as well as on the employer's website (Labour Code of the Republic of Moldova, 2003).

This concept of "transfer from full-time to part-time work or vice versa" contributed to the emergence and development of the legal doctrine, according to which part-time employment is considered as a stepping stone to full-time employment or vice versa (Cai, Law \& Bathgate, 2014).

We note that the highest level of part-time employment is observed in those countries where rules are set at the legislative level, which gives the parties more opportunities to adjust working hours to balance the employee and employer interests and ensure the employee's right to adjust the working hours. The basis of such rules is the so-called transition from full to part-time employment and vice versa (Vaganay, Canónico\&Courtin, 2016).

The Netherlands, where the level of part-time work is the highest in Europe, provides for not only the form of such an agreement, but also a consecutive order for the implementation of the relevant changes in strict accordance with the principles of contractual practice with prior notice that does not allow to unilaterally adjust the content of the employment contract. Under Netherlands labor law, an employee who works at least 26 weeks at the employer' workplace, provided prior notice not later than 2 months before the proposed date of the start of changes, has the right to change the duration of working time by submitting a written application to the employer, which should include the desired date of starting work under new conditions and the proposed working schedule. The employer has an obligation to consider the employee's initiative and the employee's request, to make a motivated written decision within a month before the employee's proposed date. At the same time, the employer has the right to participate in the negotiations with employee on harmonizing the future working schedule and to make propositions (Act of the Netherlands, 2000).

Consequently, the Netherlands labor law contains a detailed regulated procedure for changing the duration of working time for employees who have been working for a long time with this employer, using two elements of contractual practice at the same time. This is a timely notification of the other party of the intention to change the terms of the contract as concerns working time, and the negotiation process required to reach an agreement on new (already changed) working conditions.

But it is necessary to focus attention on the need for regulation of reverse transition - from part-time to full-time employment.

The so-called Bridging Part-Time Employment (Brückenteilzeit) Project aimed at remedying this situation, which was implemented in 2017 in Germany, introducing a number of changes to national legislation. It was intended to solve a number of problematic issues related to the return of an employee who worked part-time for a certain period to full-time employment.

First of all, the right to transition to part-time employment (for a period from 1 to 5 years) can be exercised by all employees who work with the employer for more than 6 months (BundesamtfürJustiz, 2000). That is, in comparison with the Netherlands labor law, the term of the labor relations of employees who can show such an initiative is significantly reduced. At the same time, Bridging Part-Time Employment (Brückenteilzeit) can only apply to employers employing more than 45 employees. 
Such an approach has been critically evaluated by the German Confederation of the Hesse-Thuringia Trade Unions in view of such data. It was noted that, according to the Federal Employment Agency, $38.7 \%$ (14.5 million) of all employees work in companies with the number of employed up to 45, among women - 42 percent (7.6 million) (Schiermeyer, 2018). Therefore, since women often work in small businesses, only a minority can take advantage of the right to return, the German Confederation of Hesse-Thuringia Trade Unions complains (Deutsche HandwerksZeitung, 2019).

Bridging part-time employment (Brückenteilzeit) provides an opportunity for the employer to refuse to switch to part-time employment not only if he has operational reasons. The role and normative ratio of the total number of employees to the part-time worker also plays a role. For example, if an employer with 45 to 60 employees already has at least 4 employees working part-time, he may refuse the transition of the workers who found the initiative (BundesamtfürJustiz, 2000).

The employer has the right to make any decision, but the law also determines the criteria that can help in formulating a valid reason. These include, for example, serious problems that could negatively affect the safety of work, operational activities of the enterprise, including the shortage of manpower (The Parliament of the United Kingdom, 1996).

An exhaustive list of reasons that allow an employer to refuse is provided by the UK legislation. For example, they include the burden of additional costs, detrimental effect on ability to meet customer demand, inability to re-organise work among existing staff, inability to recruit additional staff, detrimental impact on quality, detrimental impact on performance, insufficiency of work during the periods the employee proposes to work, planned structural changes, and such other grounds as the Secretary of State may specify by regulations (The Parliament of the United Kingdom, 1996).

If the procedure for transition to part-time employment is to some extent regulated at the level of national legislation, the return procedure is virtually outside the scope of the regulation.

Return to part-time employment may objectively require changes in staffing, redistribution of working hours, changes to the operation of the enterprise, etc. Therefore, the early notification is intended not so much to agree on the employee's work schedule, as the employee returns to the working time under previously established conditions, but intends to inform the employer in advance about the intention to return to full-time employment. As a result, the employer is not entitled to refuse the worker because everything was agreed in advance in the negotiation process regarding the conditions for transition to part-time employment.

Some practical issues regarding the execution of the right to request a flexible work schedule have been resolved in the United Kingdom in the Code of Practice, produced by the Advisory, Conciliation and Arbitration Service (Acas). Acas $\underline{(2015)}$ has also published a guidance document on rights.

The most widespread approach to studying employee requests is based on random selection to decide if unable to distinguish between all the requests (Acas, 2015, p.16). The second approach obviously should be based on the employees' needs. That is, it is advisable for the employer to make comparisons in order to identify which of the employees needs this job more in view of the ability to continue to fulfill his/her job responsibilities. In our view, the priority should also be given to people who are less socially protected in the labor market.

One way to solve this problem is local legislation, where, within the framework of social partnership, one can try to coordinate and enshrine a certain compromise solution. In particular, the law does not deprive parties to an employment contract within the content of the agreement of determining the conditions and procedure for changing the duration of working time (Sweden) (Eklund, 2004) or resolving such issues at the level of collective regulation (Spain) (Valdés DalRé, 2004). The legislation of the Netherlands contains an instruction that obliges employers with a small (less than 10) number of employees to determine the measures that will be taken at the local level with a view to adjusting the duration of working time (Act of the Netherlands, 2000).

At the same time, the UK does not have any restrictions on the number of employees of the employer regarding the right to request a flexible working schedule. In particular, firm size does not seem to have a big effect, but employees in small companies - i.e. with 10 employees or less - have more access to flexible work arrangements. The closer interpersonal links that employees in small firms often develop and the associated level of trust seems to facilitate greater responsiveness to worker needs at the workplace (OECD, 2016, p.9).

Based on the analysis, we can present a model for regulating the transition from full-time to part-time employment within the enterprise. The essence of this model is that the EU legislation and the national legislation of the EU states-member consider full employment as a traditional form of organization of labour relations. At the same time, the possibility of hiring part-time employers is established, but the conditions under which this is possible are not established at all or not clearly established. In other words, part-time work is applied to employers based on the economic condition of the enterprise and its development prospects. This gives us every reason to consider this type of labor relationship as a means of optimizing the organization of the enterprise. It was established that the national and European legislation determines only the principles of the organization of the labour process, while the features of the introduction of part-time employment are established in relation to the employee and the violation of the contract (Figure 1). 


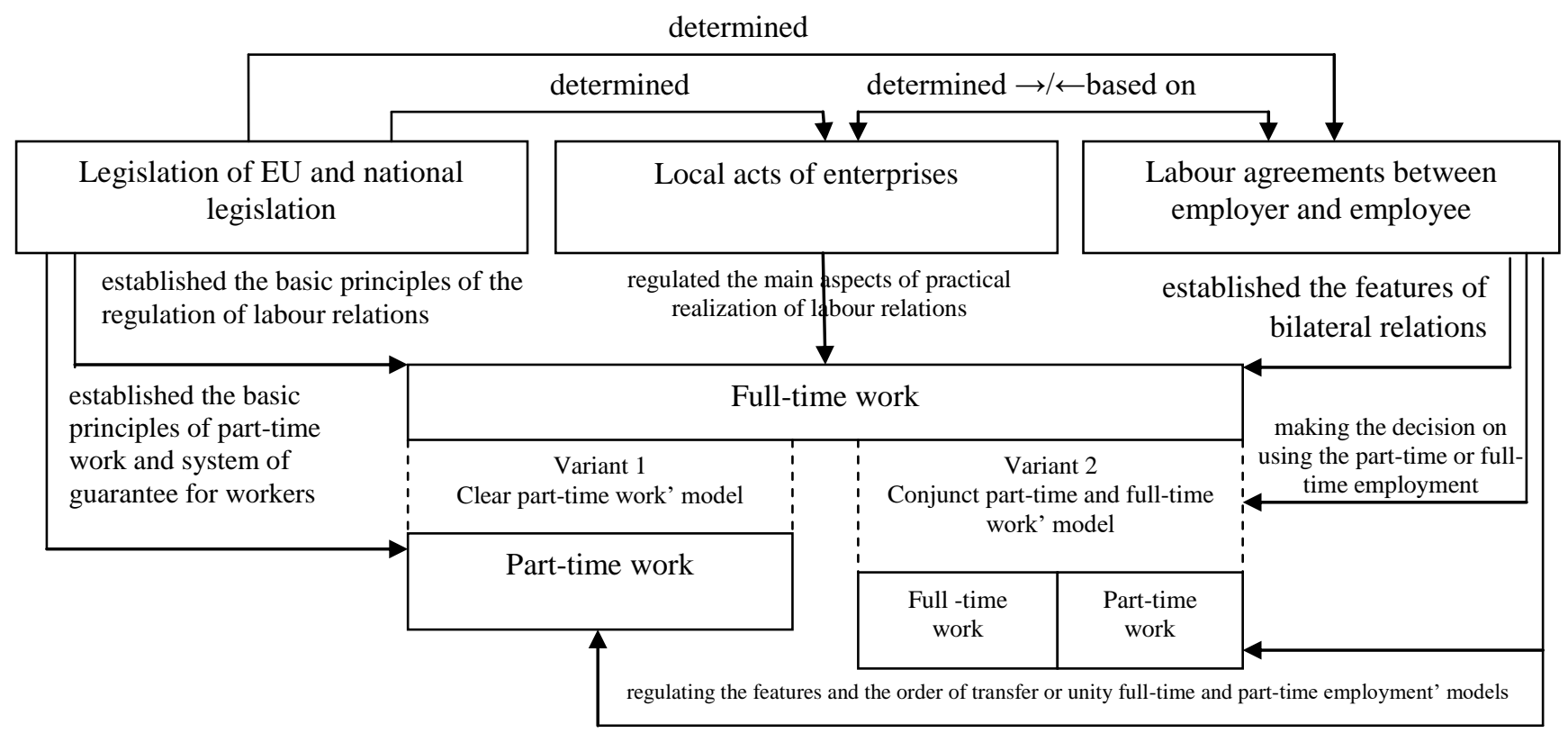

Figure 1: The model of legal and contract adjusting of transfer from full-time to part-time employment or its conjunct use

As full-time employment considered the common cause of the organization of labour relations by European and national legislation, the latter determines its principles and organizational foundations. At the level of enterprise, the main aspects of full-time or part-time employment are regulated both by legislation and by labor agreements, which are based on local acts of a particular enterprise.

\section{The operational requirements of the establishment}

The international legal regulation of part-time work involves some provisions, which form a legal mechanism for adjustment of the organizational and industrial structure of the employer if it can affect the individual labour relations with the employee.

A system analysis of their content (Council Directive 97/81/EC, 1998; ILO, 1994; 1994a) gives grounds for the conclusion that the process of transfer from full-time to part-time work or vice versa is based on the principles of voluntariness, limitedness and requires prior notice of the employee in case of certain reasons, which can be described by the term of "the operational requirements of the establishment" in accordance with national law and practice. At the same time, a temporary reduction in the duration of working time in relation to all staff, which is caused by economic, technical or structural reasons, is not defined as a part-time, but as partial unemployment. This concept should be considered as "established by unilateral employer's action rather than agreement of the employer and the employee" (Guobaitè-Kirsliene, 2010).

On the contrary, the basis of the part-time employment relationship is a specially agreed schedule, unilateral change of which is not only a violation of the contractual principles in legal relations but an attempt to intervene in private life of a person (European Court of Human Rights, 2019). This is illustrated by the decision of the Court of Justice of the European Communities, according to which, despite quite versatile assessment of the legal situation and the ambiguous interpretation of Council Directive 97/81/EC (1998) concerning the Framework Agreement on part-time work concluded by UNICE, CEEP and the ETUC, the Court of Justice of the European Union took the position that national law can provide for the following:"the employer may order the conversion of a part-time employment relationship into a full-time employment relationship without the consent of the worker concerned" (European Union Court of Justice, 2014a).

The main argument for making such a decision was that in this way the wages of the employee increase and his/her employment status is improved. However, it was not taken into account that such changes had a negative impact on individual and family life of a person, as a worker successfully combined vocational training and care for her family, she also "registered with the Trento roll of lawyers, has graduated from a specialist college for legal professions, and has also enrolled in the University of Padua" (Opinion of Advocate General Wahl, 2014).

Perhaps this resonance act of interpreting the provisions of Directive 97/81/EC concerning the Framework Agreement on part-time work concluded by UNICE, CEEP and the ETUC contributed to the changes in the national legislation of European States (The Republic of Finland, the Finnish Parliament, 2001). Therefore, in most countries, there are regulatory powers of the employer in relation to the unilateral modification of the worker's schedule with reference to objective, 
immediate measures that need to be implemented in the organizational and industrial structure of the employer. This is mainly due to the fact that such negative effects of business management (economic activity) as reducing volume of production, loss of market, difficult financial situation will not cause mass dismissals and job losses by workers.

The criteria developed in the common law of the United Kingdom and coordinated with legislative rules (The Parliament of the United Kingdom, 1996) can be used for effective and equitable resolution of such issues in other European countries. The use of these principles will improve not only the practice of law enforcement but also the interpretation of the provisions of national law.

The common law considers the principle of trust and confidence as fundamental ones for wage labor relations, which aim at supporting and developing mutual obligations of the employee and the employer.

No less important criterion used to prove the legitimacy or the unlawfulness of the employer's conduct in relation to parttime work is the principle of objectivity.

In this connection, another principle - the principle of proportionality - is used in the common law (BAILII, 2005). It is indissolubly linked to the principle of objectivity, as "“necessary' is to be qualified by the adjective 'reasonable' but the word 'reasonably' reflects the applicability of the principle of proportionality" (BAILII, 2005).

The action of two principles contributes to the more equitable and objective resolution of the labor dispute in order to ensure a balance of legal protection of the interests of both the employee and the employer.

In addition, the judicial practice has produced one of the effective methods to ensure the stability of the organizational and industrial process of the employer - job-sharing. Court of Justice of the European Communities (1998) notes that "the Labour Court takes up the position that job-sharing is in a unique category as it does not involve a break in service. The specific feature which distinguishes part-time work from job-sharing is that in case of the latter the work and responsibilities are shared between two employees".

The author believes that the objectivity of circumstances is characterized by the fact that under inevitable conditions the employer could not act otherwise than by applying such measures in order to achieve the necessary changes for the further effective implementation of his business objectives. In our opinion, the principle of proportionality is that the measure chosen by the employer in case of possible negative changes in his organizational and industrial structure should be proportional to the scope of such changes in order to stay competitive in the labour market.

\section{CONCLUSION}

We identified the several types of effective HR management models on the basis of part-time employment, based on the transition from full-time to part-time work or vice versa.

The transition to part-time employment can only take place within the labor relations between the employee and the employer. It is achieved through a combination of contractual practices such as early notification of the other party (initiative) and negotiations aimed at resolving all issues related to changing working conditions. For example, reaching a compromise with regard to the working schedule, date and time of transition, etc.

It has been found that most of the legislative rules are intended for workers of medium-sized and large enterprises (usually more than 15 employees), certain categories of employees and duration of relations (from 6 months of employment). At the same time, the combination of these three aspects makes it possible to distinguish the following models of transition from full-time to part-time work or vice versa.

\section{Permanent transition to part-time employment for all employees:}

Permanent transition is a reduction in the duration of working time without setting the period. When choosing this type of part-time employment, the employee can permanently remain in the conditions of part-time employment, unless the period for such a transition shall be indicated.

2. Temporary transition to part-time employment for all employees:

Its feature is the limited duration of part-time employment during a certain period (with the indication of a period).

\section{3. "Priority" transition to part-time employment}

This kind of transition is usually established at the level of the legal requirement addressed to the employer to provide parttime employment for a certain category of persons.

We believe that employers have the right to independently, within the framework of local regulation and HR management, develop flexible working policies, determine the rules for part-time employment arrangement, taking into account the minimum guarantees provided for by national legislation, collective agreement, and international labor standards. Ignoring these requirements may jeopardize the effective management of human resources, affect the flexibility of labour relations and the effective operation of the enterprise. 
In this regard, the local documentation of the employer must be developed in respect of those aspects that are not properly elaborated in the legislation, in particular:

1. Procedure for early notification of the employer about the intent of transition (the period of transition, the number of working hours, the desired working schedule) and the imperative for the employer to consider the application and adopt a decision on it;

2. Procedure for the employee's advance notice about the intent to return to full-time employment;

3. A list of reasons that enable the employer to refuse transition to part-time employment, taking into account the specifics of the employer's activities;

4. Rules that determine the procedure of consideration of applications for part-time employment.

The study allowed representing the model of legal and contractual regulation of transition from full-time to part-time employment or its conjuncture. This model describes the mechanism of legal regulation of labor relations in two cases. First is converting from full-time to part-time employment. The second suggested using both elements of full-time and part-time employment at the same time.

\section{REFERENCES}

1. Acas. (2015). The right to request flexible working: an ACAS guide. https://www.employmentlawwatch.com/wpcontent/uploads/sites/7/2014/07/The-right-to-request-flexible-working-the-Acas-gui.pdfAccessed 25 April 2019

2. Act of the Netherlands. (2000). The Working Hours (Adjustment). http://wetten.overheid.nl/BWBR001117 3/2016-01-01\#Opschrift. Accessed 25 April 2019.

3. AnwZ (Brfg) 58/14. (2016). Widerruf der ZulassungzurRechtsanwaltschaftwegen der Nichtvorlageeinerunwi derruflichenNebentätigkeitserlaubnisbzw. Freistellungserklärung. https://www.jurion.de/urteile/bgh/2016-1107/anwz-_brfg_-58_14/. Accessed 25 April 2019.

4. BAILII. (2005). Hardys\&Hansons Plc v Lax. Case No: A2/2004/1847.http://www.bailii.org/ew/c ases/EWCA /Civ/2005/846.html. Accessed 25 April 2019.

5. Beatson, M. (2019). The trends shaping work and working lives. https://www.cipd.co.uk/Images/megatrendsreport-flexible-working-1_tcm18-52769.pdf. Accessed 25 April 2019.

6. Blázquez Cuesta, M., \& Moral Carcedo, J. (2014). Women's part-time jobs: "Flexirisky" employment in five European countries. International Labour Review, 153(2), 269-292. https://doi.org/10.1111/j.1564913X.2014.00204.X

7. Deutsche HandwerksZeitung. (2019). "Brückenteilzeit" Das gilt ab 2019.https://www.deutsche-handwerkszeitung.de/wechsel-in-teilzeit-das-gilt-rechtlich/150/3098/292326. Accessed 27 April 2019.

8. BundesamtfürJustiz. (2000). GesetzüberTeilzeitarbeit und befristeteArbeitsverträge (Teilzeit- und Befristungsgesetz - TzBfG).https://www.gesetze-im-internet.de/tzbfg/BJNR196610000.htm 1\#BJNR196610 000BJNG000200305. Accessed 23 April 2019.

9. Cai, L., Law, V., \& Bathgate, M. (2014). Is Part-Time Employment a Stepping Stone to Full-Time Employment? Economic Record, 90(291), 462-485. https://doi.org/10.1111/1475-4932.12120

10. Cataldi, A., Kampelmann, S., \&Rycx, F. (2013). Part-time Work, Wages and Productivity: Evidence from Matched Panel Data.Discussion Paper No. 7789. Bonn: The Institute for the Study of Labor.

11. Council Directive 91/533/EEC. (1991). On an employer's obligation to inform employees of the conditions applicable to the contract or employment relationship. Official Journal of the European Communities, L 288/32, 11957E100. https://eur-lex.europa.eu/legal-content/EN/ALL/?uri=CELEX\%3A31991L0533. Accessed 25 April 2019.

12. Council Directive 97/81/EC. (1998). Concerning the Framework Agreement on part-time work concluded by UNICE, CEEP and the ETUC. Official Journal of the European Communities, L014, 0009-0014. https://eurlex.europa.eu/legal-content/EN/TXT/?uri=CELEX:31997L0081. Accessed 27 April 2019.

13. Court of Justice of the European Communities. (1998). Hill and Stapleton $v$ The Revenue Commissioners and Department of Finance. Case 243/95.http://curia.europa.eu/juris/liste.jsf?lang uage=en\&jur=C,T ,F\&num=2 43/95\&td=ALL. Accessed 27 April 2019.

14. Cuesta, M. B., \& Martın, N. E. R. (2009). Part-time employment: a comparative analysis of Spain and the Netherlands. European Journal of Law and Economics, 28(3),223. https://doi.org/10.1007/s10657-009-91097Accessed 23 April 2019. https://doi.org/10.1007/s10657-009-9109-7

15. Devicienti, F., Grinza, E., \&Vannoni, D. (2015). The Impact of Part-Time Work on Firm Total Factor Productivity: Evidence from Italy.Discussion Paper No. 9463. Bonn: The Institute for the Study of Labor.

16. Eklund, R. (2004). Sweden: part-time work - welfare or infair? In S. Sciarra, P. Daries, P. Freedland (Eds.), Employment Policy and the Regulation of Part-time Work in the European Union: A Comparative Analysis (pp. 258-299). New York: Cambridge University Press. https://doi.org/10.1017/CBO9780511495045.010

17. EUROFOUND. (2016) Working time developments in the 21st century: work duration and itsregulation in the EU.https://www.eurofound.europa.eu/publications/report/2016/industrial-relations-law-and-regulation/workingtime-developments-in-the-21st-century-work-duration-and-its-regulation-in-the-euAccessed 27 April 2019. 
18. European Commission. (2016). Commission staff working document impact assessment: Accompanying the document Draft Proposal for a Decision of the European Parliament and of the Council on establishing a European Platform to enhance cooperation in the prevention and deterrence of undeclared work.http://eurlex.europa.eu/legal-content/EN/TXT/?uri=COM:2014:0221:FIN. Accessed 25 April 2019.

19. European Commission. (2016a). Commission staff working document SWD/2017/0204 final.http://eurlex.europa.eu/legal-content/EN/TXT/?qid=1517346509738\&uri=CELEX:52017SC0204. Accessed 25 April 2019.

20. European Commission. (2017). Commission staff working document impact assessment: Accompanying the document Proposal for a Directive of the European Parliament and of the Council on transparent and predictable working conditions in the European Union.http://eur-lex.europa.eu/legal-content/SV/TXT/?uri=CELEX\%3A5201 7SC0478. Accessed 23 April 2019.

21. European Commission. (2017a). Commission staff working document impact assessment: Accompanying the document Proposal for a Directive of the European Parliament and of the Council on work-life balance for parents and carers and repealing Council Directive 2010/18/EU. https://eur-lex.europa.eu/legal-content/FI/TXT/?uri=SW D\%3A2017\%3A202\%3AFIN. Accessed 23 April 2019.

22. European Commission. (2017b). Draft joint employment report from the Commission and the Council.http://eurlex.europa.eu/legal-content/EN/TXT/?qid=1516812601642\&uri=CELEX:52017DC0674. Accessed 23 April 2019.

23. European Commission. (2018). Employment and Social Developments in Europe 2018. Luxembourg: Publications Office of the European Union.

24. European Commission/Eurostat. (2019). EU Labour Force Survey Database User Guide. https://ec.europa.eu/eurostat/documents/1978984/6037342/EULFS-Database-UserGuide.pdf. Accessed 23 April 2019.

25. European Court of Human Rights. (2019). Guide on Article 8 of the European Convention on Human Rights.https://www.echr.coe.int/Documents/Guide_Art_8_ENG.pdfAccessed 25 April 2019.

26. European Union Court of Justice. (1986).Deborah Lawrie-Blum v Land Baden-Württemberg. Case 66/85.https://eur-lex.europa.eu/legal-content/EN/TXT/?uri=CELEX\%3A61985CJ0066. Accessed 25 April 2019.

27. European Union Court of Justice. (2014). FNV KunstenInformatieen Media v Staat der Nederlanden. Case C-413/13. http://curia.europa.eu/juris/celex.jsf?celex=62013CJ0413\&lang1=en\&type=TXT\&ancre=. Accessed 25 April 2019.

28. European Union Court of Justice. (2014a). Teresa Mascellani v MinisterodellaGiustizia. Case221/13.http://curi a.europa.eu/juris/document/document.jsf?doclang=EN\&text=\&pageIndex=0\&part=1\&mode=lst \&docid=158608 $\&$ occ $=$ first \&dir $=\&$ cid=8273. Accessed 25 April 2019.

29. Eurostat. (2017). Employment statistics. http://ec.europa.eu/eurostat/statistics-explained/index.php/Employmen t_statistics. Accessed 25 April 2019.

30. Galea, C., Houkes, I., \& De Rijk, A. (2014). An insider's point of view: how a system of flexible working hours helps employees to strike a proper balance between work and personal life. The International Journal of Human Resource Management, 25(8), 1090-1111. https://doi.org/10.1080/09585192.2013.816862

31. Guobaitè-Kirslienè, R. (2010). The features of legal regulation on part-time work. Social Sciences Studies, 4(8), 317-338.

32. ILO. (1994). C175 - Part-Time Work Convention (No. 175).https://www.ilo.org/dyn/normlex/en/f?p=N ORMLEXPUB:12100:0::NO::P12100_ILO_CODE:C175. Accessed 23 April 2019.

33. ILO. (1994a). R182 - Part-Time Work Recommendation (No. 182).http://ilo.org/dyn/normlex/en/f?p= NORMLEXPUB:12100:0::NO::P12100_ILO_CODE:R182. Accessed 23 April 2019.

34. ILO. (2017). R205 - Employment and Decent Work for Peace and Resilience Recommendation (No. 205).https://www.ilo.org/dyn/normlex/en/f?p=NORMLEXPUB:12100:0::NO::P12100_ILO_CODE:R205. Accessed 23 April 2019.

35. Interinstitutional Proclamation on the European Pillar of Social Rights. (2017). Official Journal of the European Union.http://eur-lex.europa.eu/legal-content/EN/TXT/?qid=1516812601642\&uri=CELEX:32017C1213(01). Accessed 23 April 2019.

36. International Labour Office. (2016). Non-standard employment around the world: Understanding challenges, shaping prospects. Geneva: ILO.

37. International Labour Office. (2018). World Employment and Social Outlook: Trends 2018. Geneva: ILO. https://doi.org/10.1002/wow3.125

38. Kjeldstad, R., \&Nymoen, E. H. (2012). Part-Time Work and Gender: Worker versus Job Explanations. International Labour Review, 151(1/2), 85-107. https://doi.org/10.1111/j.1564-913X.2012.00136.X

39. Kyyrä, T., Arranz, J. M., \&García-Serrano, C. (2017). Does Part-Time Work Help Unemployed Workers to Find Full-Time Work? Evidence from Spain. https://www.econstor.eu/bitstream/10419/161393/1/dp10770.pdf. Accessed 23 April 2019.

40. Labour Code of the Republic of Moldova. (2003). Code Nr. 154.http://lex.justice.md/ru/326757/. Accessed 25 April 2019. 
41. Nelen, A., De Grip, A., \&Fouarge, D. (2011). Is Part-Time Employment Beneficial for Firm Productivity? Discussion Paper No. 5423. Bonn: The Institute for the Study of Labor. Accessed 25 April 2019.

42. OECD. (2016). Be Flexible! Background brief on how workplace flexibility can help European employees to balance work and family.https://www.oecd.org/els/family/Be-Flexible-Backgrounder-Workplace-Flexibility.pdf. Accessed 28 April 2019.

43. Opinion of Advocate General Wahl. (2014). Case C-221/13 Teresa Mascellani v MinisterodellaGiustizia. https://eur-lex.europa.eu/legal-content/EN/TXT/PDF/?uri=CELEX:62013CC0221\&from=PT. Accessed 27 April 2019.

44. Petrylaitè, D. (2014). Flexible Employment Forms: The Opportunity to Establish a More Favourable Working Time Regime. In H. Strzemińska\& M. Bednarski (Eds.), Working Time Trends and Prospects in the New Economy (pp. 227-238). Warsaw: InstytutPracyiSprawSocjalnych.

45. Report V(1) The Employment Relationship. (2006). ILC 95th Session.http://ilo.org/public/english/stand ards/relm/ilc/ilc95/pdf/rep-V-1.pdf. Accessed 25 April 2019.

46. Schiermeyer, M. (2018). KeinEnde der "Teilzeitfalle"? https://www.stuttgarter-nachrichten.de/inhalt.umstrittenebrueckenteilzeit-kein-ende-der-teilzeitfalle.98413594-b2e1-4971-9234-d0a8b4c26e3f.html. Accessed 25 April 2019.

47. Sciarra, S. (2004). New discourses in labor law: part-time work and the paradigm of flexibility. In S. Sciarra, P. Daries, P. Freedland (Eds.), Employment Policy and the Regulation of Part-time Work in the European Union. A Comparative Analysis (pp. 3-35). Cambridge: Cambridge University Press. https://doi.org/10.1017/CB O9780511495045.002

48. Shagvaliyeva, S., \&Yazdanifard, R. (2014). Impact of Flexible Working Hours on Work-Life Balance. American Journal of Industrial and Business Management, 4(1), 20-23. https://doi.org/10.4236/ajibm.2014.41004

49. Silim, A., \& Stirling, A. (2014). Women and flexible working. Improving female employement outcomes in Europe. IPPR.https://www.ippr.org/publications/women-and-flexible-working-improving-female-employmentoutcomes-in-europe. Accessed 23 April 2019.

50. The European Parliament and the Council. (2003). Directive 2003/88/EC. Official Journal, L 299: 00090019.https://eur-lex.europa.eu/legal-content/EN/TXT/PDF/?uri=CELEX:32003L0088\&from=NL. Accessed 28 April 2019.

51. The Parliament of the United Kingdom. (1996). Employment Rights Act.https://www.legislation.gov.uk/ukpga/19 96/18/part/IX/crossheading/minimum-period-of-notice. Accessed 25 April 2019.

52. The Republic of Finland, the Finnish Parliament. (2001). Employment contracts act 55/2001. http://www.finlex.fi/en/laki/kaannokset/2001/en20010055.pdf. Accessed 25 April 2019.

53. Vaganay, A., Canónico, E., \&Courtin, E. (2016). Evidence Review - Challenges of work-life balance faced by working families. European Commission. https://ec.europa.eu/social/main.jsp?pubId=79 04\&langId=en\&cat Id=738\&furtherPubs=yes\&. Accessed 20 April 2019.

54. Valdés Dal-Ré, F. (2004). Spain: the difficulty of marrying flexibility with security. In S. Sciarra, P. Daries, P. Freedland (Eds.), Employment Policy and the Regulation of Part-time Work in the European Union: A Comparative Analysis (pp. 224-258). New York: Cambridge University Press. https://doi.org/10.1017/CBO97 $\underline{80511495045.009}$ 